\title{
Medicinal Plants Used for the Treatment of Respiratory Diseases in Uttarakhand State of India
}

\author{
Chandra Prakash Kala \\ Ecosystem \& Environment Management, Indian Institute of Forest Management, \\ Nehru Nagar, Bhopal 462 003, Madhya Pradesh, India \\ E-mail: cpkala@yahoo.co.uk
}

KEYWORDS Air Pollution. Herbal Healers. Himalaya. Ethnomedicine. Traditional Knowledge

\begin{abstract}
Respiratory diseases in human beings are on rise, at present, due to many reasons including deteriorating air quality. Traditionally, plants are used to treat respiratory diseases. The present study, therefore, aims to identify and document plant use for treatment of respiratory diseases in Uttarakhand state of India. Interviews with local herbal healers resulted in documentation of 82 plant species as they were used to treat 7 types of respiratory diseases such as asthma, bronchitis, tuberculosis, pneumonia, influenza, lung disorder and cough and cold. The highest number of species $(\mathrm{n}=57)$ was documented for treatment of cough and cold, followed by asthma $(\mathrm{n}=27)$ and bronchitis $(\mathrm{n}=20)$. Aconitum heterophyllum, Ocimum sanctum, Punica granatum, Terminalia bellirica and Zingiber officinale were frequently used plants to treat cough and cold. These plant species if tested clinically it may open new avenues for making new drugs to treat various respiratory diseases.
\end{abstract}

\section{INTRODUCTION}

The respiratory tract in humans, which include trachea, bronchi, bronchioles, alveoli, pleura, pleural cavity, nerves, muscles and lungs, afflicts with various types of diseases. Altogether, all these diseases are placed under the category of respiratory diseases, which range from common cold - a mild ailment - to life threatening ailments such as pneumonia, tuberculosis and asthma. Worldwide, a large number of people suffer from respiratory diseases, of which 300 million alone suffer from life threatening asthma and about 250,000 people died of this alarming disease in 2005 (WHO 2008). Respiratory diseases are on rise due to many reasons including poor air quality, especially in urban areas (Kelly 2003; D'Amato et al. 2014). Inhaling contaminated air increases number of patients having respiratory diseases. Smoking and poor hygienic conditions do invite respiratory diseases (Azarpazhooh and Leake 2006; López Campos et al. 2015). The American Association for the Advancement of Science reports that 5.5 million people died worldwide in 2013 due to air pollution, of which 1.4 million deaths occurred in India (Biswas and Hartley 2016).

Despite commendable achievements in the medical science, respiratory diseases still tempt to morbidity and mortality (Suroowan and Mahomoodally 2016). In developing countries like
India the respiratory diseases are quite common due to many reasons. Smoking, which affects the respiratory system, causes about 700,000 deaths per year in India (Gajalakshmi et al. 2003). Due to unhygienic conditions the non-smokers such as children aged less than 5 years are also subjected to respiratory tract infections. Every year over 700 million episodes of acute respiratory infections and over 52 million episodes of pneumonia are known to affect the children below 5 years age in India, of which more than 400,000 die due to pneumonia (Selvaraj et al. 2014).

Traditionally, the local medical practitioners have been treating different respiratory diseases, which include asthma, pneumonia, cough and cold by using plants. Since a large section of the society, especially in the developing countries, still uses traditional medicines as the first safety measure in the healthcare (Kala et al. 2006; Bhasin 2008), the World Health Organization has recognized the importance of traditional health care systems (Goleniowski et al. 2006). The knowledge created by the traditional herbal healers over the centuries of experimentation needs to be documented in view of its historical importance for treating various respiratory diseases. The present study, therefore, was conducted in Uttarakhand state of India with a view to understand the uses of plant species for treating various respiratory diseases. The primary aim of 
this study is to document the medicinal plant species used by local people and the herbal healers for curing respiratory diseases.

\section{METHODOLOGY}

\section{Study Area}

The present study was conducted in the Indian state of Uttarakhand, which lies between $28^{\circ} 43^{\prime}$ to $31^{\circ} 8^{\prime} \mathrm{N}$ and $77^{\circ} 35^{\prime}$ to $81^{\circ} 2^{\prime}$ ' E. Uttarakhand state possesses a wide altitudinal range from $210 \mathrm{~m}$ to $7,817 \mathrm{~m}$ over the total area of 53,485 $\mathrm{km}^{2}$. It comprises of 13 districts inhabited by $10,116,752$ people according to the 2011 Census of India. The state is well-known for its biological and cultural diversity (Kala 2018). It holds diverse forests along the altitudinal gradient, which include sub-tropical, temperate and subalpine forests. The areas above sub-alpine forests are predominated by herbaceous species. Most of the geographical area of the state spans over hills therefore it has remained isolated from rest of the agricultural plains of northern India and has thus preserved some of the old practices, traditions and ethnic norms for various resource use patterns (Kala 2011, 2019). The state being a pilgrimage centre for Hindus and Sikhs, it owns the reputation as the Devbhumi - Land of the Gods. Besides, various ethnic groups including Bhotiya, Tharu, Buksa, Jaunsari and Raji live in the state (Kala 2010). Traditionally, Bhotia, Raji and Jaunsari live in higher elevation ranges of the state whereas Tharu and Buksa generally live in the foothills and the Terai region or plains. The rich plant and cultural diversity, geographical isolation and long period of people dependency on plants for curing diseases are some of the important factors for selection of Uttarakhand to carry out the present study.

\section{Survey Methods}

\section{Secondary Sources}

The extensive literature survey (including CSIR 1989; Jain 1991; Kala 2005, 2006, 2010, 2013 , 2015; Nautiyal et al. 2001; Kala and Ratajc 2012; Gaur 1999; Phondani et al. 2010; Semwal et al. 2010) was carried out for the compilation of medicinal plant species used to treat different types of respiratory diseases by the local people and the herbal healers of Uttarakhand. Different plant parts used to treat respiratory diseases were compiled along with the number of plant species used to treat number of respiratory diseases.

\section{Fieldwork}

Apart from gathering of data from secondary sources, field surveys were also undertaken in various villages and forest areas of Uttarakhand for collection of information on the availability and uses of medicinal plant species. The structured questionnaire survey was conducted for the purpose of gathering data on the types of ailments being cured by healers with the help of medicinal plants and plant parts. The information on respiratory diseases and their treatments was gathered from 60 traditional herbal healers while documenting various uses of medicinal plants. Five workshops were also organized in different districts of Uttarakhand and various groups of indigenous people including herbal healers were invited to interact and help in documentation of their knowledge on medicinal plants for curing diseases. The data was cross checked by interviewing more than three healers on the specific uses of a plant species. In order to verify the identity of medicinal plant species field visits were undertaken with herbal healers and knowledgeable persons.

\section{RESULTS}

A large number of medicinal plant species growing in different altitudes and localities of Uttarakhand are used to treat various respiratory diseases. The present study documented 82 plant species of which herbaceous plant species were highest $(n=47)$, followed by trees and shrubs ( 15 in each life form; Table 1). These 82 species were distributed across 44 families, of which Ranunculaceae, Liliaceae, Lamiaceae and Asteraceae were the most dominant families in terms of number of species $(n=4)$. Contrary to this, 23 plant families contain only single species. Different plant parts such as leaf, root, fruit, flower, seed, stem, bark and latex were used for the treatment of respiratory diseases. The underground plant parts such as root and modified stems such as rhizome, bulb and tuber of majority of species were used. 
Table 1: Medicinal plants and plant parts used for treating respiratory diseases in Uttarakhand state of India

\begin{tabular}{|c|c|c|c|c|}
\hline S. No. & Species & Family & Life form & Plant part used \\
\hline 1 & Abies pindrow Royle & Pinaceae & Tree & Bark \\
\hline 2 & Abies spectabilis (D. Don) Mirbel & Pinaceae & Tree & Leaf, bark \\
\hline 3 & Abrus precatorius L. & Fabaceae & Woody climber & Seed, root \\
\hline 4 & Achillea millefolium $\mathrm{L}$. & Asteraceae & Herb & Whole plant \\
\hline 5 & Aconitum heterophyllum Wall. & Ranunculaceae & Herb & Root \\
\hline 6 & Acorus calamus $\mathrm{L}$. & Aracease & Herb & Root \\
\hline 7 & Adhatoda zeylanica Medikus & Acanthaceae & Shrub & Leaf, flower \\
\hline 8 & Allium сера $\mathrm{L}$. & Liliaceae & Herb & Bulb \\
\hline 9 & A. sativum $\mathrm{L}$. & Liliaceae & Herb & Bulb \\
\hline 10 & Anemone rivularis Buch.-Ham. ex DC. & Ranunculaceae & Herb & Whole plant \\
\hline 11 & Anogeissus latifolia Bedd. & Combretaceae & Tree & Bark \\
\hline 12 & Asclepias curassavica L. & Asclepiadaceae & Shrub & Leaf \\
\hline 13 & Aster asteroids DC. & Asteraceae & Herb & Root \\
\hline 14 & Astragalus candolleanus Royle ex Benth. & Fabaceae & Shrub & Root \\
\hline 15 & Bauhinia variegata $\mathrm{L}$. & Caesalpiniaceae & Tree & Bark, leaf \\
\hline 16 & Bergenia ciliata (Haworth) Sternb. & Saxifragaceae & Herb & Root, leaf \\
\hline 17 & Butea monosperma (Lamk.) Kuntze & Fabaceae & Tree & Flower, bark, seed \\
\hline 18 & Calotropis procera (Aiton) Dryander & Asclepiadaceae & Shrub & Flower \\
\hline 19 & Cannabis sativa $\mathrm{L}$ & Cannabinaceae & Herb & Leaf, seed \\
\hline 20 & Carissa opeca Stapf. & Apocynaceae & Shrub & Leaf \\
\hline 21 & Carum carvi $\mathrm{L}$. & Apiaceae & Herb & Seed \\
\hline 22 & Centella asiatica (L.) Urban & Apiaceae & Herb & Flower, leaf, root \\
\hline 23 & Cerastium cerastoides (L.) Britt. & Caryophyllaceae & Herb & Whole plant \\
\hline 24 & Cinnamomum zeylanicum Nees & Lauraceae & Tree & Leaf, bark \\
\hline 25 & Cissampelos pareira L. & Menispermaceae & Climber herb & Leaf, root \\
\hline 26 & Clematis montana Buch.-Ham. ex DC. & Ranunculaceae & Woody climber & Root \\
\hline 27 & Cuscuta reflexa Roxb. & Convolvulaceae & Climber herb & Whole plant \\
\hline 28 & $\begin{array}{l}\text { Cyanoglossum zeylanicum } \\
\text { (Vehl ex Hornem.) Thunb. ex Lehmann }\end{array}$ & Boraginaceae & Herb & Leaf, root \\
\hline 29 & Datura stramonium L. & Solanaceae & Shrub & Leaf, root \\
\hline 30 & Doronicum roylei DC. & Asteraceae & Herb & Root \\
\hline 31 & Ephedra gerardiana Wall. & Ephedraceae & Shrub & Root, Stem \\
\hline 32 & Eulophia dabia (D. Don) Hoch. & Orchidaceae & Herb & Tuber \\
\hline 33 & Euphorbia hirta L. & Euphorbiaceae & Herb & Whole plant \\
\hline 34 & Ficus benghalensis L. & Moraceae & Tree & Latex \\
\hline 35 & F. racemosa $\mathrm{L}$. & Moraceae & Tree & Bark, fruit, latex \\
\hline 36 & F. religiosa $\mathrm{L}$. & Moraceae & Tree & Leaf, bark, fruit \\
\hline 37 & Fritillaria roylei $\mathrm{Hk}$. & Liliaceae & Herb & Bulb \\
\hline 38 & Galium elegans Wall. & Rubiaceae & Herb & Shoot \\
\hline 39 & $\begin{array}{l}\text { Gentianella moorcroftiana } \\
\text { (Wall. ex Griseb.) Airy-Shaw }\end{array}$ & Gentianaceae & Herb & Whole plant \\
\hline 40 & Gloriosa superba L. & Liliaceae & Herb & Root, leaf \\
\hline 41 & Hedychium spicatum Ham. ex Smith & Zingiberaceae & Herb & Rhizome \\
\hline 42 & Lomatogonium carinthiacum (Wulf.) Br. & Gentianaceae & Herb & Whole plant \\
\hline 43 & Malva verticillata $\mathrm{L}$. & Malvaceae & Herb & Leaf, root \\
\hline 44 & Myrica esculenta Buch.-Ham. ex D. Don & Myricaceae & Tree & Bark, fruit \\
\hline 45 & Nardostachys jatamansi (D. Don) DC. & Valerianaceae & Herb & Rhizome \\
\hline 46 & Nepeta glutinosa Benth. & Lamiaceae & Herb & Whole plant \\
\hline 47 & Ocimum sanctum $\mathrm{L}$. & Lamiaceae & Herb & Whole plant \\
\hline 48 & Origanum vulgare $\mathrm{L}$. & Lamiaceae & Herb & Whole plant \\
\hline 49 & Oxalis corniculata $\mathrm{L}$. & Oxalidaceae & Herb & Leaf \\
\hline 50 & Picrorhiza kurrooa Benth & Scrophulariaceae & Herb & Root \\
\hline 51 & Podophyllum hexandrum Royle & Podophyllaceae & Herb & Rhizome, fruit \\
\hline 52 & Polygonum amplexicaule Don & Polygonaceae & Herb & Root \\
\hline 53 & P. viviparum $\mathrm{L}$. & Polygonaceae & Herb & Root \\
\hline 54 & Prunella vulgaris $\mathrm{L}$. & Lamiaceae & Herb & Whole plant \\
\hline 55 & Punica granatum L. & Punicaceae & Tree & Stem, fruit cover \\
\hline
\end{tabular}

Ethno Med, 14(1-2): 1-8 (2020) 
Table 1: Contd...

\begin{tabular}{|c|c|c|c|c|}
\hline S. No. & Species & Family & Life form & Plant part used \\
\hline 56 & Ranunculus arvensis $\mathrm{L}$. & Ranunculaceae & Herb & Leaf \\
\hline 57 & Rheum australe Don. & Polygonaceae & Herb & Root, leaf \\
\hline 58 & Rhododendron anthopogon Don & Ericaceae & Shrub & Leaf \\
\hline 59 & R. campanulatum Don & Ericaceae & Shrub & Root, leaf \\
\hline 60 & Ricinus communis L. & Euphorbiaceae & Shrub & Seed, leaf \\
\hline 61 & Saussurea costus (Falc.) Lipsch. & Asteraceae & Herb & Root \\
\hline 62 & Selinum candollii DC. & Apiaceae & Herb & Root \\
\hline 63 & Silene vulgaris (Moench) Garcke & Caryophyllaceae & Herb & Leaf \\
\hline 64 & Solanum nigrum L. & Solanaceae & Herb & Fruit, leaf, seed \\
\hline 65 & Stephania glabra (Roxb.) Miers & Menispermaceae & Climber herb & Tuber \\
\hline 66 & $\begin{array}{l}\text { Swertia chiraiyta (Roxb. ex Fleming) } \\
\text { Karsten }\end{array}$ & Gentianaceae & Herb & Whole plant \\
\hline 67 & Terminalia bellirica (Gaertner) Roxb. & Combretaceae & Tree & Fruit \\
\hline 68 & Terminalia chebula Retx. & Combretaceae & Tree & Fruit, seed \\
\hline 69 & Tinospora cordifolia L. & Menispermaceae & Herb & Whole plant \\
\hline 70 & Toona ciliata Roem. & Meliaceae & Tree & Bark, fruit, leaf \\
\hline 71 & Trianthema portulacastrum L. & Aizoaceae & Herb & Root \\
\hline 72 & Tylophora indica (Burm. f.) Merr. & Asclepiadaceae & Shrub & Whole plant \\
\hline 73 & Verbascum thapsus L. & Schrophulariaceae & Herb & Whole plant \\
\hline 74 & Viola bioflora L. & Violaceae & Herb & Flower, leaf \\
\hline 75 & V. canescens Wall. & Violaceae & Herb & Leaf, flower \\
\hline 76 & V. pilosa Blume & Violaceae & Herb & Whole plant \\
\hline 77 & Vitex negundo L. & Verbenaceae & Shrub & Stem, flower, leaf \\
\hline 78 & Woodfordia fruticosa (L.) Kurz. & Lythraceae & Shrub & Flower \\
\hline 79 & Zanthoxylum armatum DC. & Rutaceae & Shrub & Fruit, stem, bark \\
\hline 80 & Zingiber officinale Roscoe & Zingiberaceae & Herb & Rhizome \\
\hline 81 & Ziziphus mauritiana Lam. & Rhamnaceae & Tree & Fruit \\
\hline 82 & Ziziphus nummularia (Burn. F.) Wight and Arn. & Rhamnaceae & Shrub & Rhizome \\
\hline
\end{tabular}

Species were used for treating 7 major types of respiratory diseases including asthma, bronchitis, tuberculosis, pneumonia, influenza, lung disorder and cough and cold (Table 2). Most of the species were used for treating a limited number of respiratory diseases. Acorus calamus was used for the treatment of 3 types of respiratory diseases. Adhatoda zeylanica, Zingiber officinale, Abies pindrow, Swertia chiraiyta and Abies spectabilis were other important species in their uses. Among the different respiratory diseases, the highest number of species $(n=57)$ was documented for treating cough and cold, followed by asthma $(n=27)$, bronchitis $(n=20)$, tuberculosis $(n=5)$, pneumonia $(n=5)$ and influenza $(n=3)$.

Of the 82 medicinal plant species used for the treatment of respiratory diseases, the following 13 are considered rare and endangered: Aconitum heterophyllum, Gloriosa superba, Nardostachys jatamansi, Ephedra gerardiana, Rheum australe, Fritillaria roylei, Podophyllum hexandrum, Picrorhiza kurrooa, Rhododendron anthopogon, R. campanulatum, Swer- tia chiraiyta, Saussurea costus and Zanthoxylum armatum. Of these 13 plant species, four species (Aconitum heterophyllum, Nardostachys jatamansi, Picrorhiza kurrooa and Saussurea costus) are in the critically endangered category; four species (Ephedra gerardiana, Rheum australe, Fritillaria roylei and Podophyllum hexandrum) in the endangered category; two species (Zanthoxylum armatum and Gloriosa superba) in the vulnerable category, and Rhododendron anthopogon and $R$. campanulatum in the near threatened category as per the IUCN red list categories.

\section{DISCUSSION}

Uttarakhand state of India is known for having a high diversity of medicinal plants. The present investigation results into documentation of highest number of medicinal plants for curing cough and cold. Most of the geographical area in the state being hilly the severe cool climatic condition invites cold related ailments

Ethno Med, 14(1-2): 1-8 (2020) 
Table 2: Plant species used for the treatment of different types of respiratory diseases in Uttarakhand state of India

\begin{tabular}{ll}
\hline S. No.Respiratory diseases & $\begin{array}{l}\text { Number of } \\
\text { plants used }\end{array}$
\end{tabular}$\quad$ Name of plant species

$1 \quad$ Cough and cold
4

5

6

(n)

\begin{tabular}{ll} 
Tuberculosis & 5 \\
Pneumonia & 5 \\
& 3 \\
Influenza & 2 \\
Lung disorder & \\
\hline
\end{tabular}

in humans for major part of the year. The traditional medicinal practitioners, therefore, would have attempted to find out herbs that could cure cold related disorders. Out of 57 plant species documented for curing cough and cold, Aconitum heterophyllum, Adhatoda zeylanica, Anem-
Abies pindrow, Abrus precatorius, Achillea millefolium, Aconitum heterophyllum, Acorus calamus, Adhatoda zeylanica, Allium sativum, Anemone rivularis, Anogeissus latifolia, Asclepias curassavica, Astragalus candolleanus, Bauhinia variegata, Calotropis procera, Cannabis sativa, Carissa opeca, Carum carvi, Centella asiatica, Cerastium cerastoides, Cinnamomum zeylanicum, Cissampelos pareira, Clematis montana, Cuscuta reflexa, Cyanoglossum zeylanicum, Doronicum roylei, Eulophia dabia, Euphorbia hirta, Ficus bengalensis, F. religiosa, Gentianella moorcroftiana, Lomatogonium carinthiacum, Malva verticillata, Myrica esculenta, Nardostachys jatamansi, Ocimum sanctum, Origanum vulgare, Oxalis corniculata, Picrorhiza kurrooa, Podophyllaum hexandrum, Polygonum amplexicaule, Prunella vulgaris, Punica granatum, Rhododendron anthopogon, Rhododendron campanulatum, Selinum candollii, Solanum nigrum, Terminalia bellirica, Terminalia chebula, Verbascum thapsus, Viola bioflora, $V$. canescens, V. pilosa, Vitex negundo, Woodfordia fruticosa, Zanthoxylum armatum, Zingiber officinale, Ziziphus mauritiana, Ziziphus nummularia

Abies spectabilis, Acorus calamus, Allium cepa, Calotropis procera,Cyanoglossum zeylanicum, Datura stramonium, Ephedra gerardiana, Euphorbia hirta, Ficus religiosa, Fritillaria roylei, Gloriosa superba, Hedychium spicatum, Myrica esculenta, Picrorhiza kurrooa, Ranunculus arvensis, Rheum australe, Saussurea costus, Selinum candollii, Silene vulgaris, Stephania glabra, Swertia chiraiyta, Tinospora cordifolia, Terminalia bellirica, Trianthema portulacastrum, Tylophora indica, Verbascum thapsus, Viola canescens

Abies pindrow, Abies spectabilis, Acorus calamus, Adhatoda zeylanica, Allium cepa, Cannabis sativa, Euphorbia hirta, Ficus racemosa, Fritillaria roylei, Galium elegans, Hedychium spicatum, Nardostachys jatamansi, Ocimum sanctum, Rheum australe, Rhododendron anthopogon, Silene vulgaris, Swertia chiraiyta, Terminalia chebula, Viola canescens, Toona ciliata

Bergenia ciliata, Butea monosperma, Centella asiatica, Stephania glabra, Zingiber officinale

Ficus racemosa, Nepeta glutinosa, Ricinus communis, Terminalia chebula, Vitex negundo

Origanum vulgare, Picrorhiza kurrooa, Swertia chiraiyta

Polygonum viviparum, Prunella vulgaris

Ethno Med, 14(1-2): 1-8 (2020)

one rivularis, Cinnamomum zeylanicum, Nardostachys jatamansi, Ocimum sanctum, Punica granatum, Terminalia bellirica, Terminalia chebula, Zanthoxylum armatum and Zingiber officinale are frequently used by the local people, even without consulting specialized herbal prac- 
titioners. The rind of pomegranate, both leathery exocarp and fleshy mesocarp, is stored for months after sun drying. The dried rind is roasted on mild fire and then chewed for curing cough. Similarly, the rhizome of Zingiber officinale is roasted and then chewed. The leaves of Ocimum sanctum are consumed either raw or as a drink by making its tea, especially for the treatment of cough and cold.

Different parts of plants are used to prepare medicine for treatment of diseases, however whole plant of 16 species (all are herbs) is used to treat respiratory diseases. These species include Anemone rivularis, Cuscuta reflexa, Euphorbia hirta, Gentianella moorcroftiana, Lomatogonium carinthiacum, Ocimum sanctum, Prunella vulgaris, Tinospora cordifolia, Verbascum thapsus, Viola pilosa and endangered Swertia chiraiyta. Over 23 plant species are uprooted as their roots and rhizomes are used to treat diseases, which include four critically endangered species (i.e., Aconitum heterophyllum, Saussurea costus, Picrorhiza kurrooa and Nardostachys jatamansi), two endangered species (e.g., Ephedra gerardiana and Rheum australe), and one vulnerable species namely Gloriosa superba. Harvesting of roots and rhizomes of such threatened species may mount extra pressure on their already limited populations.

Studies conducted elsewhere have reported plants use for the treatment of respiratory diseases. Inhabitants of Lövéte and Nagybacon villages of Transylvanian farms in Romania use 34 and 26 species of medicinal plants respectively to treat respiratory diseases (Papp et al. 2011). An ethnopharmacological analysis of traditional medicine documents 55 plant species those are used to treat 18 respiratory tract diseases in Mauritius where 81 different recipes are concocted by using these plants and oral intake is the most common route of administration (Suroowan and Mahomoodally 2016). In Urmia City, which is located in the west Azarbaijan Province of Iran, the local people use 20 medicinal plant species to treat respiratory disorders, traditionally (Asadbeigi et al. 2014). The use of plants for treating diseases is common in different provinces of Iran (Ghasemi-Pirbalouti 2013; Asadbeigi et al. 2014). In Uttarakhand, the leaves and roots of maximum number of plants are used however contrary to the present study, the peo- ple of Urmia use seeds of maximum number of species to treat respiratory diseases.

In northwest region of Cameroon where the altitude ranges from 950 to $1500 \mathrm{~m}$ above mean sea level, the local people use over 54 plant species to treat 9 types of respiratory diseases, including asthma, bronchitis, cough, pneumonia, cold and tuberculosis (Focho et al. 2009). Likewise present study, leaf is the most frequently used plant part in Cameroon which is attributed to the ability of leaf to form and store variety of medicinally useful chemical compounds through photosynthesis (Ramesh and Okigbo 2008). In KwaZulu-Natal of South Africa, over 30 plant species are used to treat respiratory diseases by the rural people by making decoctions of these plants, which is mostly taken orally along with combination of steaming (York et al. 2011).

Twenty-two plants used in Mexican traditional medicine to treat respiratory diseases when evaluated clinically for their activity against tuberculosis the Lantana hispida was emerged as an important source of potential compounds against tuberculosis (Jimenez Arellanes et al. 2003). A few plant species such as Allium sativum and A. cepa documented during the present investigation are clinically tested for their efficacy (Gupta et al. 2010), which renders very satisfactory results. This shows that medicinal plants offer a hope for developing alternate medicines for the treatment of various respiratory diseases. The present list of 82 plants is anticipated to open new avenues for making new drugs that can help to reduce sufferings of human beings.

At present, the level of toxic substances is increasing in the atmosphere, which is deteriorating the air quality. Around 300 million children live in areas where outdoor air pollution exceeds 6 times higher than international guidelines that is caused by heavy use of fossil fuels, vehicle emissions, construction, and burning of waste and seasonal stubble (UNICEF 2016). During and immediately after some of the festivals such as Diwali in India, due to intense use of firecrackers the concentration of air pollutants such as carbon monoxide, carbon dioxide, and lead increases manifold, which affects the respiratory system of people living in the immediate surroundings. Besides Diwali, Uttarakhand has the history of regular forest fire due to pre- 
dominance of chir pine (Pinus roxburghii) forest between 600-2300 m, which makes the air quality quite hazardous for its inhabitants, especially during such incidences. Therefore, apart from drawing preventive measures to keep the air clean and to discourage use of tobacco, the use of medicinal plants may help the affected communities in the areas reeling under the present pressure of air and air related pollutions.

\section{CONCLUSION}

The local people of Uttarakhand possess rich knowledge on use of plant species for treatment of various respiratory diseases. Some plant species are prominent as they are used frequently for treatment of multiple respiratory disorders. On the other hand, there are rare and endangered species used as medicines by the local people. The traditional knowledge on medicinal plants, as documented during the present study, can be used for carrying out further scientific research in order to validate and standardize the medicinal efficacy of such important plant species. Moreover, the importance of such studies and plant species has increased several folds, at present, when the air quality has become extremely substandard for the survival of human beings.

\section{ACKNOWLEDGEMENT}

Author thanks herbal healers of Uttarakhand for their help and valuable support during the course of this study.

\section{REFERENCES}

Asadbeigi M, Mohammadi T, Rafieian-Kopaei M, Saki K, Bahmani M, Delfan M 2014. Traditional effects of medicinal plants in the treatment of respiratory diseases and disorders: An ethnobotanical study in the Urmia. Asian Pacific Journal of Tropical Medicine, 7: 364-368.

Azarpazhooh A, Leake JL 2006. Systematic review of the association between respiratory diseases and oral health. Journal of Periodontology, 77(9): 14651482. doi: $10.1902 /$ jop.2006.060010

Bhasin V 2008. Gaddi's folk medicine: A source of healing. Studies on Ethno-Medicine, 2 (1): 1-27.

Biswas AK, Hartley K 2016. Foul Odour of Failure. Times of India, 8 November 2016.

CSIR 1989. The Wealth of India: Raw Materials. Publications \& Information Directorate, Council of Scientific and Industrial Research, New Delhi.
D’Amato G, Cecchi L, D'Amato M, Annesi-Maesano I 2014. Climate change and respiratory diseases. European Respiratory Review, 23(132): 161-169.

Focho DA, Nkeng EAP, Fonge BA, Fongod AN, Muh CN, Ndam TW, Afegenui A 2009. Diversity of plants used to treat respiratory diseases in Tubah, northwest region, Cameroon. African Journal of Pharmacy and Pharmacology, 3(11): 573-580.

Gajalakshmi V, Peto R, Kanaka TS, Jha P 2003. Smoking and mortality from tuberculosis and other diseases in India: retrospective study of 43000 adult male deaths and 35000 controls. The Lancet, 362 (9383): 507-515.

Gaur RD 1999. Flora of the District Garhwal Northwest Himalaya (With Ethnobotanical Notes). TransMedia, Srinagar Garhwal, India.

Ghasemi-Pirbalouti A, Momeni M, Bahmani M 2013. Ethnobotanical study of medicinal plants used by Kurd tribe in Dehloran and Abdanan districts, Ilam Province, Iran. African Journal of Tradition, Complementary and Alternative Medicine, 10(2): 368385 .

Goleniowski ME, Bongiovanni GA, Bongiovanni L, Palacio CO, Cantero JJ 2006. Medicinal plants from the "Sierra de Comechingones". Argentina Journal of Ethnopharmacology, 107(3): 324-341.

Gupta R, Thakur B, Singh P, Singh HB, Sharma VD, Katoch VM, Chauhan SVS 2010. Anti-tuberculosis activity of selected medicinal plants against multidrug resistant Mycobacterium tuberculosis isolates. Indian Journal of Medical Research, 131(6): 809813

Jain SK 1991. Dictionary of Indian Folk Medicine and Ethnobotnay. New Delhi Deep Publications.

Jimenez Arellanes A, Meckes M, Ramirez R, Torres J, Luna Herrera J 2003. Activity against multidrug resistant Mycobacterium tuberculosis in Mexican plants used to treat respiratory diseases. Phytotherapy $R e-$ search, 17(8): 903-908.

Kala CP 2005. Current status of medicinal plants used by traditional Vaidyas in Uttaranchal state of India. Ethnobotany Research and Applications, 3: $267-$ 278 .

Kala CP 2006. Preserving Ayurvedic herbal formulations by Vaidyas: The traditional healers of the Uttaranchal Himalaya region in India. HerbalGram, 70: $42-50$.

Kala CP 2010. Medicinal Plants of Uttarakhand: Diversity, Livelihood and Conservation. Delhi, India: Biotech Books.

Kala CP 2011. Medicinal plants used for dermatological disorders: a study of Uttarakhand state in India. Australian Journal of Medical Herbalism, 23(3): $132-137$.

Kala CP 2013. Indigenous knowledge, use of NTFPs and biodiversity conservation in Uttarakhand. In: CP Kala, CS Silori (Eds.): Biodiversity, Communities and Climate Change. New Delhi: The Energy and Resources Institute, pp. 245-255.

Kala CP 2015. Medicinal and aromatic plants of tons watershed in Uttarakhand Himalaya. Applied Ecology and Environmental Sciences, 3(1): 16-21.

Ethno Med, 14(1-2): 1-8 (2020) 
Kala CP 2018. Uses, population status and management of Betula utilis. Applied Ecology and Environmental Sciences, 6(3): 79-83.

Kala CP 2019. Medicinal plants used for treatment of fever and headache in Uttarakhand state of India. Journal of Non-Timber Forest Products, 26(1): 3944.

Kala CP, Dhyani PP, Sajwan BS 2006. Developing the medicinal plants sector in northern India: Challenges and opportunities. Journal of Ethnobiology and Ethnomedicine, 2: 32. DOI: 10.1186/1746-42692-32.

Kala CP, Ratajc P 2012. High altitude biodiversity of the Alps and the Himalayas: Ethnobotany, plant distribution and conservation perspective. Biodiversity and Conservation, 21(4): 1115-1126.

Kelly FJ 2003. Oxidative stress: its role in air pollution and adverse health effects. Occupational and Environmental Medicine, 60(8): 612-616.

López Campos JL, Tan W, Soriano JB 2015. Global burden of COPD. Respirology, 21 (1): 14-23.

Nautiyal S, Maikhuri RK, Rao KS, Saxena KG 2001. Medicinal plant resources in Nanda Devi Biosphere Reserve in the central Himalayas. Journal of Herbs, Spices \& Medicinal Plants, 8(4): 47-64.

Papp N, Bartha S, Boris G, Balogh L 2011. Traditional uses of medicinal plants for respiratory diseases in Transylvania. Natural Product Communications, 6(10): 1459-1460.

Phondani PC, Maikhuri RK, Rawat LS, Farooquee NA, Kala CP, Vishvakarma SCR, Rao KS, Saxena KG 2010. Ethnobotanical Uses of Plants among the Bhotiya Tribal Communities of Niti Valley in Cen- tral Himalaya, India. Ethnobotany Research and Applications, 8: 233-244.

Ramesh P, Okigbo RN 2008. Effects of medicinal plant combinations as anti-infectives. African Journal of Pharmacy and Pharmacology, 2(7): 130135 .

Selvaraj K, Chinnakali P, Majumdar A, Krishnan IS 2014. Acute respiratory infections among under-5 children in India: A situational analysis. Journal of Natural Science, Biology and Medicine, 5(1): 1520. doi: 10.4103/0976-9668.127275

Semwal DP, Saradhi PP, Kala CP, Sajwan BS 2010. Medicinal plants used by local vaidyas in Ukhimath block, Uttarakhand. Indian Journal of Traditional Knowledge, 9(3): 480-485.

Suroowan S, Mahomoodally MF 2016. A comparative ethnopharmacological analysis of traditional medicine used against respiratory tract diseases in Mauritius. Journal of Ethnopharmacology, 177: 61-80.

UNICEF 2016. Clear the Air for Children: The Impact of Air Pollution on Children. United Nations Children's Fund. From<http://www.unicef.org/publications/files/UNICEF_Clear_the_Air_for_Children 30_Oct_2016.pdf $>$.

WHO 2008. Global Alliance Against Chronic Respiratory Diseases Action Plan 2008-2013. World Health Organization, Geneva, Switzerland.

York T, De Wet H, Van Vuuren SF 2011. Plants used for treating respiratory infections in rural Maputaland, KwaZulu-Natal, South Africa. Journal of Ethnopharmacology, 135(3): 696-710.

Paper received for publication in September, 2019 Paper accepted for publication in November, 2019

Ethno Med, 14(1-2): 1-8 (2020) 